\title{
Article \\ Quantity- and Quality-Based Farm Water Productivity in Wine Production: Case Studies in Germany
}

\author{
Denise Peth ${ }^{1}$, Katrin Drastig ${ }^{1, *}$ and Annette Prochnow ${ }^{1,2}$ \\ 1 Leibniz-Institute for Agricultural Engineering and Bioeconomy, Max-Eyth-Allee 100, 14469 Potsdam, \\ Germany; denise.peth@posteo.de (D.P.); aprochnow@atb-potsdam.de (A.P.) \\ 2 Faculty of Life Sciences, Humboldt-University of Berlin, Hinter der Reinhardtstr. 8-18, \\ 10115 Berlin, Germany \\ * Correspondence: kdrastig@atb-potsdam.de; Tel.: +49-331-5699-218
}

Academic Editors: Tim Hess and Jerry Knox

Received: 29 November 2016; Accepted: 24 January 2017; Published: 1 February 2017

\begin{abstract}
The German wine sector has encountered new challenges in water management recently. To manage water resources responsibly, it is necessary to understand the relationship between the input of water and the output of wine, in terms of quantity and quality. The objectives of this study are to examine water use at the farm scale at three German wineries in Rhenish Hesse, and to develop and apply, for the first time, a quality-based indicator. Water use is analyzed in terms of wine production and wine-making over three years. After the spatial and temporal boundaries of the wineries and the water flows are defined, the farm water productivity indicator is calculated to assess water use at the winery scale. Farm water productivity is calculated using the AgroHyd Farmmodel modeling software. Average productivity on a quantity basis is $3.91 \mathrm{~L}$ wine per $\mathrm{m}^{3}$ of water. Productivity on a quality basis is 329.24 Oechsle per $\mathrm{m}^{3}$ of water. Water input from transpiration for wine production accounts for $99.4 \%-99.7 \%$ of total water input in the wineries, and, because irrigation is not used, precipitation is the sole source of transpired water. Future studies should use both quality-based and mass-based indicators of productivity.
\end{abstract}

Keywords: Germany; wine production; water productivity; AgroHyd Farmmodel

\section{Introduction}

Agricultural productivity enhancements result from implementing practices that improve soil, crop, and water management. The first step in achieving efficient water use is to identify water demand and influencing factors. Several recent case studies concerning the idea of a water footprint in the wine sector, based on the water footprint concept and life cycle assessment (LCA), have been published.

The concept of the water footprint considers the amount of water used by a product during its journey along the supply chain, as well as the amount of water indirectly associated with the product's creation that is used by people or to provide a service. Several methods exist to assess the water footprint (which is based on the concept of virtual water extended by a spatiotemporal component). These techniques divide the water used or consumed into three different classes: green water (rainwater stored in the soil), blue water (freshwater available from surface and ground resources), and grey water (freshwater that is theoretically needed to dilute polluted water to reach ambient water quality standards) [1,2]. Studies dealing with the concept of the water footprint in wine production have been conducted in Portugal [3], Romania [4], New Zealand [5], and Italy [6]. In addition, one study calculated a global average value [7]. Water demand ranged from 438 to $1754 \mathrm{~L}$ of water to produce one bottle containing $0.75 \mathrm{~L}$ of wine (i.e., 584 to $2339 \mathrm{~L}$ of water per $\mathrm{L}$ of wine).

LCA studies in the wine-producing sector that collected information about water use have been conducted in Italy [8-11], Spain [12-16], Portugal [17], and Romania [18]. In these studies, water 
demand varied from 0.73 to $1065.09 \mathrm{~L}$ of water per bottle of wine (i.e., 0.97 to $1420.12 \mathrm{~L}$ per $\mathrm{L}$ of wine). Different methods to estimate water use lead to different results, making it difficult to compare, classify, and evaluate water demand. Determining the water footprint includes evapotranspiration from precipitation, whereas LCA only considers blue water use. The aim of LCA is to quantify all inputs and outputs throughout the life cycle of a product and to evaluate potential impacts on the environment [19].

The method of farm water indicators [20] differs from the LCA and the water footprint approach in the way that it considers the farm scale and the amount of water necessary to build up biomass. Farm indicators calculated based on case studies can provide direct insights into water demand and suggest ways to make farm water management more efficient. Case study research for theory development and testing in operations management is one of the most powerful research methods [21,22]. Case studies generally offer a low possibility of repetition and only a narrow and limited base for generalization - this should be recognized. However, they can provide rich descriptions, explorations, and explanations of the phenomena being studied. Case studies are of particular use when little prior study has been undertaken [23].

The method presented here has not been applied to the wine sector in Germany or internationally and will be tested by using three case studies. Furthermore, the concept of water productivity defined by mass output to water input may not be appropriate for wineries, because wine is mainly defined by its product quality rather than by quantity. The product quality dictates the price of a bottle of wine, so the expected income of a winemaker is substantially influenced by the quality of the product. Therefore, it is important to perform a quality-based evaluation of water demand in wine production.

The objective of the present work is to test a method to calculate water-related indicators based on three case studies at the farm scale in German wine production. This includes the development and first application of a quality-based indicator. Farm water productivity, degree of water utilization, and specific technical water inflow are calculated for three German wine farms over the course of three years. The indicator of farm water productivity is extended to a quality basis.

\section{Materials and Methods}

\subsection{System Boundaries and Data}

The water productivity of wine production is analyzed at a farm scale. This system takes into consideration any physical component that belongs to the farm. Hence, vineyard area and winery buildings are part of the system [20]. The different production stages comprise the work in the vineyard and the wine cellar. The reference period is based on the period between harvest of the previous year and the harvest of the current year, which includes the different crop growth stages of the vegetation period. The reference period may differ from field to field.

Farm data are collected from three wineries in Southwest Germany. The three wineries were selected because they are located in the largest wine-producing region in Germany and have a mean vineyard area size representative for this region. The investigated specialist vineyards are in Rhenish Hesse, the largest wine-producing region in Germany. The main grape varieties grown on the farms are Müller-Thurgau, Riesling, Silvaner, Dornfelder, and Portugieser. The farms had a vineyard area of between 9.7 and 14.5 ha in the years considered (between 2011 and 2013), which is representative for an average Rhenish specialist vineyard, which has a size of 11.2 ha [24]. Mean harvest yield is around $10,000 \mathrm{~L} / \mathrm{ha}$ [25]. Table 1 gives an overview of the farm characteristics. 
Table 1. Farm characteristics.

\begin{tabular}{cccc}
\hline Winery/Data Source & Farm Size & $\begin{array}{c}\text { Form of Marketing (Bulk } \\
\text { Wine/Bottled Wine) }\end{array}$ & $\begin{array}{c}\text { Grape Variety (White } \\
\text { Wine/Red Wine) }\end{array}$ \\
\hline Winery I & $9.6 \mathrm{ha}$ & $40 \% / 60 \%$ & $66 \% / 34 \%$ \\
Winery II & $14.3 \mathrm{ha}$ & $45 \% / 55 \%$ & $73 \% / 27 \%$ \\
Winery III & $9.4 \mathrm{ha}$ & $50 \% / 50 \%$ & $81 \% / 19 \%$ \\
Rheinhessen & $11.2 \mathrm{ha} \mathrm{(in} \mathrm{2010)}$ & $\mathrm{n} / \mathrm{a}$ & $69 \% / 31 \%$ (in 2013) \\
Statistisches [24,25] & & &
\end{tabular}

Soil data are provided by the Harmonized World Soil Database [26]. The dominant soil types in the analyzed region are loamy sand and sandy loam (Ls3, S14). Climate data are obtained from weather stations of Agricultural Meteorology, run by the Centre of Rural Services in Rhineland-Palatine [27]. The vineyards were a minimum of $200 \mathrm{~m}$ and a maximum of $7 \mathrm{~km}$ from the weather station. Mean annual temperature and precipitation for the balance periods (starting in October of the previous year, and ending in September of the balance reference year) for 2011, 2012, and 2013 are shown in Table 2.

Table 2. Weather data for the three farms investigated.

\begin{tabular}{ccccccc}
\hline \multirow{2}{*}{ Winery } & \multicolumn{3}{c}{ Mean Annual Temperature $\left({ }^{\circ} \mathbf{C}\right)$} & \multicolumn{3}{c}{ Precipitation (mm) } \\
\cline { 2 - 7 } & $\mathbf{2 0 1 1}$ & $\mathbf{2 0 1 2}$ & $\mathbf{2 0 1 3}$ & $\mathbf{2 0 1 1}$ & $\mathbf{2 0 1 2}$ & $\mathbf{2 0 1 3}$ \\
\hline Winery I & 10.6 & 10.8 & 9.9 & 504 & 483 & 559 \\
Winery II & 10.6 & 10.8 & 9.9 & 504 & 483 & 559 \\
Winery III & 11.2 & 11.3 & 10.4 & 524 & 531 & 598 \\
\hline
\end{tabular}

The timeframe of modeling, including start and endpoints, is presented in Table 3. Local climate data, crop data, and soil dataand the vineyard areas were combined in a modeling unit for detailed calculation of the local hydrologic processes: evaporation from soil, transpiration, rainfall interception loss, and percolation. In this study, 550 modeling units were obtained from the vineyard areas. Water flows were calculated for each modeling unit on a daily basis for three years. For each modeling unit, daily data on temperature, precipitation, relative air humidity, sunshine duration, and wind speed from the next closest station were used.

Table 3. The timeframe of the modeling start (one day after harvest in the previous year) and modeling end (day of harvest in the current year). Some modeling units had different start and end dates. The number of modeling units matches the number of vineyard areas.

\begin{tabular}{|c|c|c|c|c|}
\hline & nery & 2011 & 2012 & 2013 \\
\hline \multirow{3}{*}{ Winery I } & Start & $\begin{array}{l}21 \text { September- } \\
6 \text { October } 2010\end{array}$ & $\begin{array}{l}4 \text { September- } \\
5 \text { October } 2011\end{array}$ & $\begin{array}{l}25 \text { September- } \\
18 \text { October } 2012\end{array}$ \\
\hline & End & $\begin{array}{l}3 \text { September- } \\
4 \text { October } 2011\end{array}$ & $\begin{array}{l}24 \text { September- } \\
17 \text { October } 2012\end{array}$ & $\begin{array}{l}1 \text { September- } \\
21 \text { October } 2013\end{array}$ \\
\hline & $\begin{array}{l}\text { Number of } \\
\text { modeling units }\end{array}$ & 43 & 43 & 38 \\
\hline \multirow{3}{*}{ Winery II } & Start & $\begin{array}{l}12 \text { September- } \\
5 \text { October } 2010\end{array}$ & $\begin{array}{l}5 \text { September- } \\
5 \text { October } 2011\end{array}$ & $\begin{array}{l}19 \text { September- } \\
17 \text { October } 2012\end{array}$ \\
\hline & End & $\begin{array}{l}4 \text { September- } \\
4 \text { October } 2011\end{array}$ & $\begin{array}{c}18 \text { September- } \\
16 \text { October } 2012\end{array}$ & $\begin{array}{l}26 \text { September- } \\
23 \text { October } 2013\end{array}$ \\
\hline & $\begin{array}{l}\text { Number of } \\
\text { modeling units }\end{array}$ & 72 & 72 & 71 \\
\hline \multirow{3}{*}{ Winery III } & Start & $\begin{array}{c}8 \text { September- } \\
17 \text { October } 2010\end{array}$ & $\begin{array}{c}9 \text { September- } \\
12 \text { October } 2011\end{array}$ & $\begin{array}{l}21 \text { September- } \\
1 \text { November } 2012\end{array}$ \\
\hline & End & $\begin{array}{c}8 \text { September- } \\
11 \text { October } 2011\end{array}$ & $\begin{array}{l}2 \text { September- } \\
31 \text { October } 2012\end{array}$ & $\begin{array}{c}1 \text { October- } \\
25 \text { October } 2013\end{array}$ \\
\hline & $\begin{array}{c}\text { Number of } \\
\text { modeling units }\end{array}$ & 72 & 71 & 68 \\
\hline
\end{tabular}




\subsection{Calculation of Farm Water Productivity}

\subsubsection{Definition of Farm Water Productivity}

Generally, productivity is defined as output per unit of input. In the case of farm water productivity, the input is water and the output may be defined as the mass of products, amount of food energy, or amount of income generated [20]. In the present case study, we use mass as the indicator and develop a quality-based indicator. Calculating an energy- or income-based indicator in the case of wine would not be suitable for two reasons. First, wine is not a basic foodstuff, but a luxury product that does not satisfy the human food energy demand. Second, the price span of a bottle of wine is very wide and mainly depends on the wine quality.

Water inflow $\left(\mathrm{W}_{\text {inflow }}\right)$ is defined as the sum of water that enters the system, including precipitation, surface flows, subsurface flows, and technical water (tap water and irrigation water) [20]. Furthermore, per Prochnow et al. [20], the water input includes all water flows that contribute to the generation of output. Therefore, the transpiration from precipitation, the technical water, and the indirect water demand are summarized. The sum of those fractions of water inflow that are used for crop growth within the farm boundaries: transpired water stemming from precipitation $\left(\mathrm{W}_{\text {prec-trans }}\right)$, plus all water inflow via technical means $\left(W_{\text {tech }}\right)$, plus indirect water use referring to pre-chains (e.g., for feed production) $\left(W_{\text {indirect }}\right)$ is defined as Water input $\left(W_{\text {input }}\right)$ :

$$
\mathrm{W}_{\text {input }}=\mathrm{W}_{\text {prec-trans }}+\mathrm{W}_{\text {tech }}+\mathrm{W}_{\text {indirect }}
$$

Water transpired by plants $\left(\mathrm{W}_{\text {transp }}\right)$ is equal to transpired water stemming from precipitation $\left(\mathrm{W}_{\text {prec-trans }}\right)$ if no irrigation water is applied. In this case, the productive water $\left(\mathrm{W}_{\text {prod }}\right)$ equals the water transpired by plants ( $\left.W_{\text {transp }}\right)$.

Calculating farm water productivity based on mass reveals how much mass output is produced per unit water input. Output is defined as wine in liters. To calculate farm water productivity based on mass $\left(\mathrm{L} / \mathrm{m}^{3}\right)$, the following formula is used:

$$
\text { FWPmass }=\frac{\text { Mass }_{\text {output }}}{W_{\text {input }}}
$$

Since quality is the decisive parameter in wine production, an additional indicator is introduced to account for the quality of the output. The new quality-based indicator for farm water productivity considers the must weight as a quality indicator. In Germany, the must weight defines the wine quality classification. A higher must weight indicates higher quality. In Germany, must weight is measured in degrees Oechsle ( ${ }^{\circ} \mathrm{Oe}$ ), a measure of the "specific gravity of a sugar solution" (in this case, wine must after harvest). Measurement is performed by a refractometer, calibrated in degrees Oechsle at a temperature of $20^{\circ} \mathrm{C}$ [28]. Other countries use different measurement units [29]. For example, Austria uses the Klosterneuburger Mostwaage $\left({ }^{\circ} \mathrm{KMW}\right)$. Other scales include degrees Brix $\left({ }^{\circ} \mathrm{Bx}\right)$ and degrees Baumé ( ${ }^{\circ}$ Bé) [28].

One advantage of using the must weight as a quality indicator is that quality can be measured objectively. Normally, quality is perceived subjectively by wine consumers and is, therefore, difficult to compare.

Farm water productivity on a quality basis $\left({ }^{\circ} \mathrm{Oe} / \mathrm{m}^{3}\right)$ is calculated as follows:

$$
\text { FWPquality }=\frac{\text { Quality }_{\text {output }}}{W_{\text {input }}}
$$

\subsubsection{Calculation of Crop Transpiration (from Precipitation)}

Crop transpiration is calculated by using the AgroHyd Farmmodel [30] daily over the observation period. This software runs on the Sponge JS modeling platform [30]; at different scales, from the farm 
scale, using individual farm operating data, up to the regional scale water flow can be systematically quantified. Using the modeling software AgroHyd Farmmodel, water flows can be modeled and systematically quantified at different scales, from the farm scale (Brazilian broiler farms [31]), to the regional scale (feeding rations in Brandenburg [32]; Irrigation water demand in Germany [33,34]). Data from different sources (local climate, crop, soil, and farm data) are combined in modeling units to provide detailed modeling of the local hydrological processes. These processes are evaporation from the soil, transpiration, rainfall, interception loss, percolation, and technical water demand in wineries. In the present study, up to 187 modeling units from the vineyard areas of the wineries were used for wine production under humid conditions each year (Table 3).

The AgroHyd Farmmodel is based on the FAO 56 dual crop coefficient method under nonstandard conditions [35]. This method requires calculating (a) the reference evapotranspiration $\left(\mathrm{ET}_{0}\right)$, (b) the potential crop transpiration $\left(\mathrm{T}_{\mathrm{c}}\right)$, and $(\mathrm{c})$ the actual transpiration $\mathrm{T}_{\mathrm{act}}$ from the three different datasets for climate, plants, and soil containing regional climate data, plant-specific parameters, and regional soil data. Implemented in the AgroHyd Farmmodel are the following three steps. With regional climate data $\mathrm{ET}_{0}$ of a grass reference surface is calculated using the FAO Penman-Monteith equation. To model $\mathrm{T}_{\mathrm{C}}$, the $\mathrm{ET}_{0}$ is adjusted for the individual crop with plant-specific parameters (e.g., the plant-specific basal crop coefficient $\left(\mathrm{K}_{\mathrm{cb}}\right)$ ). Plant-specific parameters are provided in Table 4 . To determine the water stress coefficient that reduces $T_{c}$ to $T_{\text {act }}$ a daily soil water balance approach is combined with regional soil and precipitation data. By linking the datasets on plant, soil, and climate the calculation of $\mathrm{T}_{\text {act }}$ incorporates the effect of daily water stress due to water-limited conditions. Furthermore, the deep percolation of water through the soil, total available soil water in the root zone, root zone depletion, evaporation, and evapotranspiration are calculated following Allen et al. [35]. For a detailed description of the model, see Drastig et al. [32] and Prochnow et al. [20]. The amount of irrigation water required to ensure maximum security of the water supply to the crops grown could be calculated using the Agrohyd Farmmodel. However, because the vineyards were not irrigated, the irrigation demand is not modeled. For calibration purposes of the AgroHyd Farmmodel single water flow components were analyzed by comparing model results to measured values for actual evapotranspiration based on lysimeter measurements in the Weimar region in Thuringia (Central Germany) for the crops spring barley, winter wheat, and potato [36], and in Hesse (Central Germany) for oat [37]. The calibration results can be seen in $[33,34]$. To the knowledge of the authors for the calibration of the water flows in wine production no lysimeter measurements were available.

Table 4. Plant coefficients used to calculate crop transpiration.

\begin{tabular}{cccccc}
\hline Plant & $\begin{array}{c}\text { Basal Crop } \\
\text { Coefficient (-) }[35,38]\end{array}$ & $\begin{array}{c}\text { Leaf Area Index (-) } \\
{[39,40]}\end{array}$ & $\begin{array}{c}\text { Rooting Depth } \\
(\mathbf{m})[41]\end{array}$ & $\begin{array}{c}\text { Average Fraction } \\
\text { of Available Soil } \\
\text { Water (-) }[35,42]\end{array}$ & $\begin{array}{c}\text { Plant Height } \\
(\mathbf{m})[43]\end{array}$ \\
\hline Vine & 0.8 & 2.3 & 2.0 & 0.4 & 2.2 \\
\hline
\end{tabular}

The weather data of the weather stations of the Centre of Rural Services [27] are used to calculate the actual crop transpiration. Table 4 shows the basal crop coefficient $\left(\mathrm{K}_{\mathrm{cb}}\right)$, leaf area index $(\mathrm{LAI})$, rooting depth $\left(\mathrm{Z}_{\mathrm{r}}\right)$, average fraction of available soil water $(\mathrm{p})$, and plant height $(\mathrm{h})$ of vines, adjusted to the climatic and specific local conditions in Germany. We adapt the LAI value of 2.3 from Lopes [39] where LAI was measured as leaf area per unit ground surface area for a German vineyard. LAI was directly measured by collecting the leaves from a sample of 16 randomized vineyard subplots with a size of $1.4 \mathrm{~m} \times 3.6 \mathrm{~m}$. Leaf area was then calculated by scanned images of the dried leaves.

\subsubsection{Technical Water Use}

Technical water is defined as all water inflows produced by technical means and is the sum of irrigation water and tap water. Water demand in wine production includes two stages. The vineyard phase is composed of the transpiration of the plant and the technical water used for irrigation, 
fertilization, and pesticide application. The second phase includes water needed in the wine cellar for wine-making, washing and cleaning, bottling, and packaging, as well as the water used by employees.

None of the wineries used irrigation during the study period. Water demand for pesticide application was included in the technical water demand.

The three wineries differ in their production steps. While wineries I and II outsource the bottling of wine, winery III has its own bottling plant. Winery 1 also outsources labeling and packaging of wine bottles.

The relationship of technical water to farm size $\left(\mathrm{A}_{\text {farm }}\right)$ is calculated using the following formula, the specific technical water inflow $\left(\mathrm{m}^{3} / \mathrm{ha} / \mathrm{a}\right)$ :

$$
\mathrm{STW}=\frac{\mathrm{W}_{\text {techt }}}{\mathrm{A}_{\mathrm{farm}}}
$$

The productive water $\left(\mathrm{W}_{\text {prod }}\right)$ includes the water flows that contribute to the generation of biomass through plants and is composed of water taken up and transpired by plants $\mathrm{W}_{\text {transp }}\left(\mathrm{m}^{3}\right)$ that originates in precipitation and irrigation.

The degree of water utilization (DWU) describes the relationship between productive water, and total water inflow. This indicator identifies the share of water that contributes to the generation of biomass:

$$
\mathrm{DWU}=\frac{\mathrm{W}_{\text {prod }}}{\mathrm{W}_{\text {inflow }}}
$$

\subsubsection{Indirect Water}

Indirect water is the volume of water used to produce feed purchased outside the farm and all other farm inputs, such as building materials, machinery, energy, fertilizers, pesticides, herbicides, ancillary materials, and so forth. The indirect water demand is not considered in the present study, because it is assumed to be negligible. Wineries do not import plant biomass (e.g., feed purchased from outside the farm); animal farming takes the highest share of indirect water demand [31,32,44]. Water demand for the production of fertilizer, electricity, and fuel is marginal [45], as is the indirect water demand of buildings [46].

\subsubsection{Volume of a Bottle of Wine}

The volume of a bottle of wine was assumed to be $0.75 \mathrm{~L}$. The calculation process was:

$$
\text { FWPmass }\left(\mathrm{L} / \mathrm{m}^{3}\right)=\text { FWPmss }\left(\text { Bottle } / \mathrm{m}^{3} \times 0.75\right)
$$

\section{Results}

The water flows of the three investigated wineries are presented in Table 5. Water inflow varied $4 \%-13 \%$ within the three investigated years from the mean of the three years. The water inflow of all wineries consists of $99.4 \%-99.7 \%$ precipitation. The remaining water flow is the technical water. The vines were not irrigated during the observation period, so technical water is composed only of tap water. Transpiration from precipitation accounted for $98.7 \%-99.4 \%$ of the water input. 
Table 5. Water input for Winery I, II, and III.

\begin{tabular}{|c|c|c|c|c|c|c|c|c|c|c|c|c|}
\hline \multirow{2}{*}{$\begin{array}{c}\text { Winery } \\
\text { Year }\end{array}$} & \multicolumn{4}{|c|}{ Winery I } & \multicolumn{4}{|c|}{ Winery II } & \multicolumn{4}{|c|}{ Winery III } \\
\hline & 2011 & 2012 & 2013 & Mean & 2011 & 2012 & 2013 & Mean & 2011 & 2012 & 2013 & Mean \\
\hline \multicolumn{13}{|c|}{ Water Flows $\left(\mathrm{m}^{3}\right)$} \\
\hline Water inflow ${ }^{a} \mathrm{~W}_{\text {inflow }}$ & 47,529 & 47,145 & 53,900 & 49,525 & 71,254 & 67,994 & 84,164 & 74,471 & 49,463 & 50,682 & 56,532 & 52,226 \\
\hline Precipitation $W_{\text {prec }}$ & 47,322 & 46,952 & 53,651 & 49,308 & 71,008 & 67,750 & 83,927 & 74,228 & 49,148 & 50,367 & 56,217 & 51,911 \\
\hline Technical water $\mathrm{W}_{\text {tech }}$ & 207 & 193 & 249 & 216 & 246 & 244 & 237 & 242 & 315 & 315 & 315 & 315 \\
\hline Irrigation water $\mathrm{W}_{\text {irri }}$ & - & - & - & - & - & - & - & - & - & - & - & - \\
\hline Tap water $\mathrm{W}_{\text {tap }}$ & 207 & 193 & 249 & 216 & 246 & 244 & 237 & 242 & 315 & 315 & 315 & 315 \\
\hline Water input ${ }^{\mathrm{b}} \mathrm{W}_{\text {input }}$ & 24,977 & 23,260 & 24,571 & 24,269 & 37,537 & 34,761 & 39,250 & 37,183 & 28,656 & 24,431 & 28,887 & 27,325 \\
\hline $\begin{array}{l}\text { Transpiration stemming } \\
\text { from precipitation } W_{\text {prec-trans }}\end{array}$ & 24,770 & 23,067 & 24,322 & 24,053 & 37,291 & 34,517 & 39,013 & 36,940 & 28,341 & 24,116 & 28,572 & 27,010 \\
\hline Indirect water $\mathrm{W}_{\text {indirect }}$ & - & - & - & - & - & - & - & - & - & - & - & - \\
\hline Productive water $W_{\text {prod }}$ & 24,770 & 23,067 & 24,322 & 24,053 & 37,291 & 34,517 & 39,013 & 36,940 & 28,341 & 24,116 & 28,572 & 27,010 \\
\hline $\mathrm{W}_{\text {transp }}$ & 24,770 & 23,067 & 24,322 & 24,053 & 37,291 & 34,517 & 39,013 & 36,940 & 28,341 & 24,116 & 28,572 & 27,010 \\
\hline
\end{tabular}

a Water inflow: Sum of water that enters the system, including precipitation, surface flows, subsurface flows, and technical water (tap water and irrigation water); ${ }^{\mathrm{b}}$ Water input: Water flows that contribute to the generation of output. The sum of those fractions of water inflow that are used for crop growth within the farm boundaries: transpired water stemming from precipitation, plus all water inflow via technical means, plus indirect water use referring to pre-chains. 
Table 6 describes the output in terms of mean yield per hectare and as must weight (an indicator of quality).

Table 6. Wineries' outputs as the mean yield per hectare and the respective must weights.

\begin{tabular}{ccccccccc}
\hline \multirow{2}{*}{ Winery/Region } & \multicolumn{3}{c}{ Mean Yield Per Hectare (hL/ha) } & \multicolumn{3}{c}{ Mean Must Weight $\left({ }^{\circ}\right.$ Oe) } \\
\cline { 2 - 9 } & $\mathbf{2 0 1 1}$ & $\mathbf{2 0 1 2}$ & $\mathbf{2 0 1 3}$ & Mean & $\mathbf{2 0 1 1}$ & $\mathbf{2 0 1 2}$ & $\mathbf{2 0 1 3}$ & Mean \\
\hline Winery I & 106.2 & 103.6 & 89.9 & 99.9 & 78 & 87 & 79 & 81.3 \\
Winery II & 111.4 & 100.2 & 104.1 & 105.2 & 80 & 89 & 82 & 83.7 \\
Winery III & 140.2 & 98.3 & 112.8 & 117.1 & 89 & 88 & 83 & 86.7 \\
Rhenish Hesse [25,47,48] & 101.4 & 101.3 & 98.5 & 100.4 & 80 & 83 & 78 & 80.3 \\
\hline
\end{tabular}

The resulting water input per $\mathrm{L}$ wine is shown in Table 7.

Table 7. Water input per liter of wine.

\begin{tabular}{ccccccccc}
\hline Winery & \multicolumn{3}{c}{ Liter Water Input per Liter Wine } & \multicolumn{3}{c}{ Liter Technical Water per Liter Wine } \\
\hline Year & $\mathbf{2 0 1 1}$ & $\mathbf{2 0 1 2}$ & $\mathbf{2 0 1 3}$ & Mean & $\mathbf{2 0 1 1}$ & $\mathbf{2 0 1 2}$ & $\mathbf{2 0 1 3}$ & Mean \\
\hline Winery I & 249 & 238 & 304 & 263 & 2.1 & 2.0 & 3.1 & 2.4 \\
Winery II & 241 & 248 & 269 & 252 & 1.6 & 1.7 & 1.6 & 1.6 \\
Winery III & 220 & 271 & 286 & 259 & 2.4 & 3.5 & 3.1 & 3.0 \\
Mean & 237 & 252 & 286 & 258 & 2.0 & 2.4 & 2.6 & 2,3 \\
\hline
\end{tabular}

The farm water indicators are shown in Tables 8 and 9. Since output and quality in 2013 were comparatively low and transpiration was high, water productivity was below average.

Table 8. Water-related indicators for Wineries I, II, and III.

\begin{tabular}{|c|c|c|c|c|c|c|}
\hline Indicator $^{\mathbf{a}}$ & Unit & Year & Winery I & Winery II & Winery III & Mean \\
\hline \multirow{4}{*}{ FWPmass } & \multirow{4}{*}{$\mathrm{L} / \mathrm{m}^{3}$} & 2011 & 4.02 & 4.16 & 4.55 & 4.24 \\
\hline & & 2012 & 4.21 & 4.04 & 3.69 & 3.98 \\
\hline & & 2013 & 3.29 & 3.71 & 3.50 & 3.50 \\
\hline & & Mean & 3.84 & 3.97 & 3.91 & 3.91 \\
\hline \multirow{4}{*}{ FWPquality } & \multirow{4}{*}{${ }^{\circ} \mathrm{Oe} / \mathrm{m}^{3}$} & 2011 & 311.62 & 333.38 & 402.99 & 349.33 \\
\hline & & 2012 & 365.70 & 361.35 & 332.62 & 353.22 \\
\hline & & 2013 & 259.36 & 304.66 & 291.47 & 285.16 \\
\hline & & Mean & 312.23 & 333.13 & 342.36 & 329,24 \\
\hline \multirow{4}{*}{ WUE } & \multirow{4}{*}{$\mathrm{m}^{3} / \mathrm{L}$} & 2011 & 0.25 & 0.24 & 0.22 & 0.24 \\
\hline & & 2012 & 0.24 & 0.25 & 0.27 & 0.25 \\
\hline & & 2013 & 0.30 & 0.27 & 0.29 & 0.29 \\
\hline & & Mean & 0.26 & 0.25 & 0.26 & 0.26 \\
\hline \multirow{4}{*}{ DWU } & \multirow{4}{*}{-} & 2011 & 0.52 & 0.52 & 0.57 & 0.54 \\
\hline & & 2012 & 0.49 & 0.51 & 0.48 & 0.49 \\
\hline & & 2013 & 0.45 & 0.46 & 0.51 & 0.47 \\
\hline & & Mean & 0.49 & 0.50 & 0.52 & 0.50 \\
\hline \multirow{4}{*}{ STW } & \multirow{4}{*}{$\mathrm{m}^{3} / \mathrm{ha} / \mathrm{a}$} & 2011 & 21.32 & 17.16 & 33.06 & 23.84 \\
\hline & & 2012 & 19.88 & 17.02 & 33.49 & 23.46 \\
\hline & & 2013 & 26.92 & 16.53 & 34.28 & 25.91 \\
\hline & & Mean & 22.71 & 16.90 & 33.61 & 24.40 \\
\hline
\end{tabular}

${ }^{a}$ FWPmass = farm water productivity on a mass basis; FWPquality = farm water productivity on a quality basis; WUE = water use efficiency; DWU = degree of water utilization; STW = specific technical water inflow. 
Table 9. Water productivity on a mass basis $\left(\mathrm{L} / \mathrm{m}^{3}\right)$ and on a quality basis $\left({ }^{\circ} \mathrm{Oe} / \mathrm{m}^{3}\right)$ (SD = standard deviation).

\begin{tabular}{|c|c|c|c|c|c|c|c|c|c|}
\hline \multirow{2}{*}{ Winery } & \multicolumn{5}{|c|}{$\begin{array}{l}\text { Water Productivity on Mass Basis } \\
\qquad\left(\mathrm{L} / \mathrm{m}^{3}\right)\end{array}$} & \multicolumn{4}{|c|}{$\begin{array}{l}\text { Water Productivity on Quality Basis } \\
\qquad\left({ }^{\circ} \mathrm{Oe} / \mathrm{m}^{3}\right)\end{array}$} \\
\hline & Year & Mean & Min & Max & SD & Mean & Min & Max & SD \\
\hline \multirow{3}{*}{ Winery I } & 2011 & 4.06 & 1.46 & 8.00 & 1.50 & 341.15 & 117.06 & 600.28 & 103.48 \\
\hline & 2012 & 4.25 & 1.09 & 6.92 & 1.31 & 394.74 & 121.58 & 614.30 & 103.14 \\
\hline & 2013 & 3.33 & 0.96 & 5.27 & 1.00 & 280.33 & 88.26 & 421.34 & 73.69 \\
\hline \multirow{3}{*}{ Winery II } & 2011 & 4.20 & 0.83 & 8.01 & 1.82 & 382.43 & 60.05 & 678.66 & 122.00 \\
\hline & 2012 & 4.08 & 1.30 & 7.28 & 1.39 & 394.22 & 120.68 & 655.20 & 103.16 \\
\hline & 2013 & 3.74 & 1.14 & 6.12 & 1.30 & 345.34 & 102.16 & 493.50 & 111.33 \\
\hline \multirow{3}{*}{ Winery III } & 2011 & 4.60 & 1.37 & 7.20 & 1.46 & 456.16 & 109.22 & 661.48 & 130.54 \\
\hline & 2012 & 3.71 & 1.57 & 7.29 & 0.76 & 343.04 & 149.42 & 663.21 & 68.50 \\
\hline & 2013 & 3.54 & 1.17 & 5.94 & 1.21 & 325.61 & 101.88 & 463.60 & 84.90 \\
\hline
\end{tabular}

\section{Discussion}

The highest water input per liter of wine produced occurred in the year 2013 and appears to be the result of favorable weather. During that year, higher precipitation led to higher transpiration from precipitation. Water productivity on a field scale varied considerably. High-yielding grape varieties are characterized by high water productivity values. To a lesser extent, the differences in productivity are due to differing reference periods (Table 3) and different soil types. The differing reference periods may limit our ability to compare the wineries.

A reduced yield of grapes is often associated with high-quality wine. It has been shown that techniques, such as winter pruning or cluster thinning in which grape yield is reduced, lead to higher wine quality [49,50]. Therefore, a newly developed quality-based indicator was applied to measure water productivity. This new indicator may not be applicable to international comparisons due to differences in the units used to measure quality ("degrees Grad Oechsle" in Germany). The definition of wine quality in different countries varies as well.

The degree of water utilization was close to 0.5 for all investigated wineries, but the specific technical water inflow varied between the three wineries. This finding was because winery III has its own bottling plant and, therefore, uses more technical water than its competitors. However, the technical water inflow is marginal in all three wineries because the fields are not irrigated and only tap water is used.

Water use efficiency $\left(\mathrm{m}^{3} / \mathrm{L}\right)$ is the reciprocal of farm water productivity. On a mass basis, it indicates how much water input is required to generate one unit of output. Water demand per bottle of wine was, on average, $194 \mathrm{~L}$, including $1.8 \mathrm{~L}$ technical water. Since there are many methodological approaches to measuring water productivity, it is difficult to compare the results of the present study with those of previous studies. An overview of the wine sector may be found in Petti et al. [51]. For example, the concept of water footprint based on the Virtual Water concept considers the evapotranspiration of the plants, as well as the transpiration. Since the AgroHyd Farmmodel can calculate evapotranspiration as well, it is possible to provide the first comparative values for German wine (327 L per bottle). The results are shown in Table 9, subdivided into green and blue water. For the two most common approaches, the water footprint and the LCA, no comparable German study exists. In the case of water footprint, the average amount of water worldwide needed to produce one bottle of wine is 652 L [7]. Other studies reported amounts of 438 to 1754 L [3,4], compared with the calculated water demand in the present study, which is only $327 \mathrm{~L}$. In most studies, additional water was used for irrigation, a practice that is not very common in German viticulture yet. Due to local climate conditions and different soil types in the observed countries, there are large variations in reported water demand. In addition, the system boundaries are not consistent with the different studies, and the present study did not consider grey water. 
Some of the existing LCA studies of wine production state the technical water demand. In our analysis, average technical water demand was 1.2-2.6 L per bottle of wine, depending on the year and winery. In the studies that we compared, processing water used in the wine cellar accounted for 0.08-5.34 L [14,52], with one extreme value of $16.8 \mathrm{~L}$ for an Italian organic producer [11]. The amount of water used during different steps of production varied a great deal in these studies, making it difficult to accurately compare technical water demand.

Within Germany, technical water demand may be classified per the results of a survey conducted in 2000 in the state of Rhineland-Palatinate, where water demand was reported to be $4.4 \mathrm{~L}$ per $\mathrm{L}$ of wine produced, on average [53]. The average value in the present study $(1.8 \mathrm{~L})$ was less than half this amount, perhaps the consequence of technical innovations in wine cellar equipment within the past decade. Nevertheless, we recommend that wineries continue to apply water-reducing measures to limit their consumption of technical water. Since precipitation is generally free of charge, while technical water is usually billed, farmers should pay special attention to water inflows by technical means.

The major share of the water input in wine production originated from transpiration from precipitation. There were large differences in water productivity on the field scale. Although wine-makers cannot influence the amount of precipitation, it is possible for them to control transpiration by implementing certain cultivation measures, such as canopy management. For example, Williams and Ayars [54] emphasize the relationship between grapevine water use and the crop coefficient $\mathrm{K}_{\mathrm{c}}$.

\section{Conclusions}

Based on case studies at the farm scale in German wine production, water-related indicators were calculated. The three investigated case studies offer a low possibility of repetition and only a narrow and limited base for generalization from the total area of three wineries of about 33 ha to Germany, which has thirteen wine-producing areas with a total vineyard area of 102,000 ha. However, the three case studies provide descriptions, explorations, and explanations of the water use in German specialist vineyards. The water demand of three German wineries was mainly determined by the amount of transpiration that occurred, and this water came from precipitation. Of note, the vineyards that we examined were not irrigated during the study period.

This study might improve the wine production at the farm scale by applying of a quality reflecting indicator in wine production. This allows the incorporating of the quality aspects in wine production. It is important to remember that wine is a quality product. Therefore, we recommend using the quality-based indicator of water productivity developed and applied here in addition to the mass-based indicator in assessments of water productivity, degree of water utilization, and specific technical water inflow.

Ranges of the indicators farm water productivity and degree of water utilization will be derived from further investigations. These ranges may help to improve water use through single and combined farming measures for improving the water use in specialist vineyards. Indicators of known technologies and practices-identified via farm demonstration plots or a combination of on-farm experiments and simulation modeling - are a useful way for the improving of water productivity in general. It has to be taken into account, that the indicators are affected by environmental circumstances in crop production (besides the effects of different methods for the calculation) like climate, year and harvest date, and characteristics of the grape varieties.

The present study had some limitations. The AgroHyd Farmmodel did not consider green cover or other cover crops. Studies have shown that cover crops can affect the water demand of grapevines, especially as competitors for water consumption. Hofmann [55] noted that water stress in vineyards that have cover crops can result in quality and yield losses. The AgroHyd Farmmodel will be continuously expanded further. Specific attention will be given to uncertainty analysis, which is missing in this study. 
In addition, the present study did not assess young grapevines, because no plant coefficients exist for them in the scientific literature. One of the defining characteristics of young vines compared with older vines is that young vines have shorter roots. Therefore, they cannot obtain water from deeper soil layers, especially when they are affected by water stress in hot summers. Furthermore, the yields from young plants are low or zero during the first few years, corresponding to very low water productivity values.

The surface runoff characteristics of steep vineyards were not considered in the AgroHyd Farmmodel, which might influence the resulting values for water productivity. In steep-slope vineyards, surface runoff can be reduced, for example, by cover crops [53].

Further research is needed to determine plant coefficients for different grape varieties, steep-slope vineyards, and young plants to account for their characteristics while modeling water demand. Moreover, future research should address how water productivity with regard to quality products can be applied in an international context and how irrigation could affect farm water productivity.

Acknowledgments: The authors gratefully acknowledge financial support by the Leibniz Competition within the Joint Initiative for Research and Innovation of the Leibniz Association (Grant Number: SAW-2011-ATB-5). The authors gratefully acknowledge the support from three anonymous reviewers.

Author Contributions: Annette Prochnow developed the idea; Denise Peth collected the data; Denise Peth and Katrin Drastig analyzed the data; Denise Peth, Annette Prochnow, and Katrin Drastig wrote the paper.

Conflicts of Interest: The authors declare no conflict of interest.

\section{Abbreviations}

The following abbreviations are used in this manuscript:

$\begin{array}{ll}\text { A }_{\text {farm }} & \text { farm size } \\ \text { DWU } & \text { degree of water utilization } \\ \text { FWPmass } & \text { farm water productivity on a mass basis } \\ \text { FWPquality } & \text { farm water productivity on a quality basis } \\ \mathrm{K}_{\mathrm{cb}} & \text { basal crop coefficient } \\ \text { LAI } & \text { leaf area index } \\ \text { Mass output } & \text { farm output on a mass basis } \\ \mathrm{p} & \text { average fraction of available soil water } \\ \text { Qualityoutput } & \text { farm output on a quality basis } \\ \text { STW } & \text { specific technical water inflow } \\ W_{\text {indirect }} & \text { indirect water } \\ W_{\text {inflow }} & \text { water inflow, sum of water that enters the system } \\ W_{\text {input }} & \text { water input, water flows that contribute to the generation of farm output } \\ W_{\text {irri }} & \text { irrigation water } \\ W_{\text {prec }} & \text { precipitation } \\ W_{\text {prec-trans }} & \text { transpiration stemming from precipitation } \\ W_{\text {prod }} & \text { productive water } \\ W_{\text {tech }} & \text { technical water } \\ W_{\text {transp }} & \text { water taken up and transpired by plants } \\ Z_{\mathrm{r}} & \text { rooting depth }\end{array}$

\section{References}

1. Aldaya, M.M.; Chapagain, A.K.; Hoekstra, A.Y.; Mekonnen, M.M. The Water Footprint Assessment Manual: Setting the Global Standard; Routledge: New York, NY, USA, 2012.

2. Chapagain, A.; Hoekstra, A.Y. Water Footprints of Nations, Value of Water Research Report Series No. 16; UNESCO-IHE: Delft, The Netherlands, 2004. 
3. De Pina, L.A.B.; Dias, A.C.; Neto, B.; Arroja, L.; Quinteiro, P. The Water Footprint of Wine Production in Portugal: A Case Study on Vinho Verde. In Proceedings of the 6th International Conference on Industrial Ecology (ISIE 2011 Conference), Berkeley, CA, USA, 7-10 June 2011; University of California: Berkeley, CA, USA.

4. Ene, S.A.; Teodosiu, C.; Robu, B.; Volf, I. Water footprint assessment in the winemaking industry: A case study for a Romanian medium size production plant. J. Clean. Prod. 2013, 43, 122-135. [CrossRef]

5. Herath, I.; Green, S.; Horne, D.; Singh, R.; McLaren, S.; Clothier, B. Water footprinting of agricultural products: Evaluation of different protocols using a case study of New Zealand wine. J. Clean. Prod. 2013, 44, 159-167. [CrossRef]

6. Lamastra, L.; Suciu, N.A.; Novelli, E.; Trevisan, M. A new approach to assessing the water footprint of wine: An Italian case study. Sci. Total Environ. 2014, 490, 748-756. [CrossRef] [PubMed]

7. Mekonnen, M.M.; Hoekstra, A.Y. The green, blue and grey water footprint of crops and derived crop products. Hydrol. Earth Syst. Sci. 2011, 15, 1577-1600. [CrossRef]

8. Ardente, F.; Beccali, G.; Cellura, M.; Marvuglia, A. Poems: A case study of an Italian wine-producing firm. Environ. Manag. 2006, 38, 350-364. [CrossRef] [PubMed]

9. Benedetto, G. The environmental impact of a Sardinian wine by partial life cycle assessment. Wine Econ. Policy 2013, 2, 33-41. [CrossRef]

10. Notarnicola, B.; Tassielli, G.; Nicoletti, G. Life cycle assessment (LCA) of wine production. In Environmentally-Friendly Food Processing; Mattsson, B., Sonesson, U., Eds.; Woodhead Publishing Limited: Cambridge, UK, 2003; pp. 306-326.

11. Pizzigallo, A.C.I.; Granai, C.; Borsa, S. The joint use of lca and energy evaluation for the analysis of two Italian wine farms. J. Environ. Manag. 2008, 86, 396-406. [CrossRef] [PubMed]

12. Aranda, A.; Zabalza, I.; Scarpellini, S. Economic and environmental analysis of the wine bottle production in Spain by means of life cycle assessment. Int. J. Agric. Resour. Gov. Ecol. 2005, 4, 178-191. [CrossRef]

13. Gazulla, C.; Raugei, M.; Fullana-i-Palmer, P. Taking a life cycle look at Crianza wine production in Spain: Where are the bottlenecks? Int. J. Life Cycle Assess. 2010, 15, 330-337. [CrossRef]

14. Jimenez, E.; Martinez, E.; Blanco, J.; Perez, M.; Graciano, C. Methodological approach towards sustainability by integration of environmental impact in production system models through life cycle analysis: Application to the rioja wine sector. Simul. Trans. Soc. Model. Simul. Int. 2014, 90, 143-161. [CrossRef]

15. Vázquez-Rowe, I.; Villanueva-Rey, P.; Iribarren, D.; Moreira, M.T.; Feijoo, G. Joint life cycle assessment and data envelopment analysis of grape production for vinification in the rías Baixas appellation (NW Spain). J. Clean. Prod. 2012, 27, 92-102. [CrossRef]

16. Villanueva-Rey, P.; Vázquez-Rowe, I.; Moreira, M.T.; Feijoo, G. Comparative life cycle assessment in the wine sector: Biodynamic vs. Conventional viticulture activities in NW Spain. J. Clean. Prod. 2014, 65, 330-341. [CrossRef]

17. Neto, B.; Dias, A.C.; Machado, M. Life cycle assessment of the supply chain of a portuguese wine: From viticulture to distribution. Int. J. Life Cycle Assess. 2013, 18, 590-602. [CrossRef]

18. Comandaru, I.M.; Bârjoveanu, G.; Peiu, N.; Ene, S.-A.; Teodosiu, C. Life cycle assessment of wine: Focus on water use impact assessment. Environ. Eng. Manag. J. 2012, 11, 533-543.

19. ISO 14044:2006 Environmental Management_Life Cycle Assessment_Requirements and Guidelines; International Organization for Standard: Geneva, Switzerland, 2006.

20. Prochnow, A.; Drastig, K.; Klauss, H.; Berg, W. Water use indicators at farm scale: Methodology and case study. Food Energy Secur. 2012, 1, 29-46. [CrossRef]

21. Yin, R.K. Case Study Research, 5th ed.; SAGE Publications Ltd.: Los Angeles, CA, USA, 2014.

22. Voss, C.; Tsikriktsis, N.; Frohlich, M. Case research in operations management. Int. J. Oper. Prod. Manag. 2002, 22, 195-219. [CrossRef]

23. Yin, R.K. The case study method as a tool for doing evaluation. Curr. Sociol. 1992, 40, 121-137. [CrossRef]

24. Statistisches Landesamt Rheinland-Pfalz. Die Landwirtschaft 2011. Available online: http://www.statistik. rlp.de/fileadmin/dokumente/baende/band400_die_landwirtschaft_2011.pdf (accessed on 30 January 2017). (In German)

25. Statistisches Landesamt Rheinland-Pfalz. Weinbau. 2014. Available online: https://www.destatis.de/ GPStatistik/servlets/MCRFileNodeServlet/RPHeft_derivate_00004076/Faltblatt_Weinbau_2014.pdf; jsessionid=8CCCB911051B89AD1F7FD9143DA36862 (accessed on 30 January 2017). (In German) 
26. FAO; IIASA; ISRIC; ISSCAS; JRC. Harmonized World Soil Database; FAO: Rome, Italy; IIASA: Luxemburg, 2012.

27. Rheinland-Pfalz, Agrarmeterologie. Dienstleistungszentren Ländlicher Raum in Rheinland-Pfalz. Available online: www.am.rlp.de (accessed on 30 January 2017). (In German)

28. Ball, D.W. Concentration scales for sugar solutions. J. Chem. Educ. 2006, 83, 1489. [CrossRef]

29. Hopfer, H.; Nelson, J.; Ebeler, S.E.; Heymann, H. Correlating wine quality indicators to chemical and sensory measurements. Molecules 2015, 20, 8453-8483. [CrossRef] [PubMed]

30. Drastig, K.; Kraatz, S.; Libra, J.; Prochnow, A.; Hunstock, U. Implementation of hydrological processes and agricultural management options into the ATB-Modeling Database to improve the water productivity at farm scale. Agron. Res. 2013, 11, 31-38.

31. Drastig, K.; Palhares, J.C.P.; Karbach, K.; Prochnow, A. Farm water productivity in broiler production: Case studies in Brazil. J. Clean. Prod. 2016, 135, 9-19. [CrossRef]

32. Krauß, M.; Kraatz, S.; Drastig, K.; Prochnow, A. The influence of dairy management strategies on water productivity of milk production. Agric. Water Manag. 2015, 147, 175-186. [CrossRef]

33. Drastig, K.; Prochnow, A.; Libra, J.; Koch, H.; Rolinski, S. Irrigation water demand of selected agricultural crops in Germany between 1902 and 2010. Sci. Total Environ. 2016, 569, 1299-1314. [CrossRef] [PubMed]

34. Drastig, K.; Libra, J.; Kraatz, S.; Koch, H. Relationship between irrigation water demand and yield of selected crops in Germany between 1902 and 2010: A modeling study. Environ. Earth Sci. 2016, 75. [CrossRef]

35. Allen, R.G.; Pereira, L.S.; Raes, D.; Smith, M. Crop Evapotranspiration: Guidelines for Computing Crop Water Requirements; FAO: Rome, Italy, 1998; Volume 56.

36. Roth, D. Wasserhaushaltsgrößen von Kulturpflanzen unter Feldbedingungen-Ergebnisse der tll-Lysimeterstation; Thüringer Landesanstalt für Landwirtschaft: Jena, Germany, 2005; p. 159. (In German)

37. Ernstberger, H. Einfluss der Landnutzung auf Verdunstung und Wasserbilanz: Bestimmung der Aktuellen Eapotranspiration von Unterschiedlich Genutzten Standorten zur Ermittlung d. Wasserbilanz von Einzugsgebieten in Unteren Mittelgebirgslagen Hessens; Justus-Liebig-Universität-Gießen, FB Geowissenschaften: Kirchzarten, Germany, 1987. (In German)

38. Rupp, D. Optimierte Bewässerung auf der Basis der Bodenwasserbilanz unter Berücksichtigung örtlicher sowie regionaler Wetterdaten. In Qualitätsmanagement im Obst- und Weinbau; Achilles, A., Ed.; Kuratorium für Technik und Bauwesen in der Landwirtschaft e.V. (KTBL): Darmstadt, Germany, 2004; Volume 421. (In German)

39. Lopes, C.; Monteiro, A.; Ruckert, F.E.; Gruber, B.; Steinberg, B.; Schultz, H.R. Transpiration of grapevines and co-habitating cover crop and weed species in a vineyard. A "snapshot" at diurnal trends. Vitis 2004, 43, 111-117.

40. Siegfried, W.; Sacchelli, M.; Viret, O.; Wohlhauser, R.; Raisigl, U.; Huber, B. Blattflächenbezogene Dosierung von Pflanzenschutzmitteln im Rebbau. Teil i: Methoden zur Bestimmung der Blattfläche-und Laubwandentwicklung. Schweiz. Z. Obst Weinbau 2005, 4, 13-16. (In German)

41. Campos, I.; Neale, C.M.U.; Calera, A.; Balbontin, C.; Gonzalez-Piqueras, J. Assessing satellite-based basal crop coefficients for irrigated grapes (Vitis vinifera L). Agric. Water Manag. 2010, 98, 45-54. [CrossRef]

42. Doorenbos, J.; Pruitt, W.O. Crop Water Requirements-Guidelines for Predicting Crop Water Requirements; FAO: Rome, Italy, 1977.

43. Bauer, K. Weinbau; Österreichischer Agrarverlag: Wien, Austria, 2008. (In German)

44. Krauß, M.; Keßler, J.; Prochnow, A.; Kraatz, S.; Drastig, K. Water productivity of poultry production: The influence of different broiler fattening systems. Food Energy Secur. 2015, 4, 76-85. [CrossRef]

45. De Boer, I.J.M.; Hoving, I.E.; Vellinga, T.V.; Van de Ven, G.W.J.; Leffelaar, P.A.; Gerber, P.J. Assessing environmental impacts associated with freshwater consumption along the life cycle of animal products: The case of dutch milk production in noord-brabant. Int. J. Life Cycle Assess. 2013, 18, 193-203. [CrossRef]

46. Döring, K.; Kraatz, S.; Prochnow, A.; Drastig, K. Indirect water demand of dairy farm buildings. Agric. Eng. Int. 2013, 15, 16-22.

47. Statistisches Landesamt Rheinland-Pfalz. Vorläufige Weinmosternte 2012. Available online: https://www.statistik.rlp.de/fileadmin/dokumente/berichte/C2043_201200_1j_AnbGeb.pdf (accessed on 30 January 2017). (In German)

48. Statistisches Landesamt Rheinland-Pfalz. Vorläufige Weinmosternte 2013. Available online: https://www.statistik.rlp.de/fileadmin/dokumente/berichte/C2043_201200_1j_AnbGeb.pdf (accessed on 30 January 2017). (In German) 
49. Bravdo, B.; Hepner, Y.; Loinger, C.; Cohen, S.; Tabacman, H. Effect of crop level on growth, yield and wine quality of a high yielding carignane vineyard. Am. J. Enol. Vitic. 1984, 35, 247-252.

50. Gil, M.; Esteruelas, M.; Gonzalez, E.; Kontoudakis, N.; Jimenez, J.; Fort, F.; Canals, J.M.; Hermosin-Gutierrez, I.; Zamora, F. Effect of two different treatments for reducing grape yield in vitis vinifera cv syrah on wine composition and quality: Berry thinning versus cluster thinning. J. Agric. Food Chem. 2013, 61, 4968-4978. [CrossRef]

51. Petti, L.; Arzoumanidis, I.; Benedetto, G.; Bosco, S.; Cellura, M.; De Camillis, C.; Fantin, V.; Masotti, P.; Pattara, C.; Raggi, A.; et al. Life cycle assessment in the wine sector. In Life Cycle Assessment in the Agri-Food Sector; Notarnicola, B., Salomone, R., Petti, L., Renzulli, P.A., Roma, R., Cerutti, A.K., Eds.; Springer International Publishing: Bologna, Italy, 2015; p. 390.

52. Fusi, A.; Guidetti, R.; Benedetto, G. Delving into the environmental aspect of a Sardinian white wine: From partial to total life cycle assessment. Sci. Total Environ. 2014, 472, 989-1000. [CrossRef] [PubMed]

53. Staatliche Forschungsanstalt für Landwirtschaft. Weinbau und Gartenbau Forschungsprojekt PIUS; Produktionsintegrierter Umweltschutz im Weinbau; Abschlußbericht: Neustadt/Wstr, Germany. (In German)

54. Williams, L.E.; Ayars, J.E. Grapevine water use and the crop coefficient are linear functions of the shaded area measured beneath the Canopy. Agric. For. Meteorol. 2005, 132, 201-211. [CrossRef]

55. Hofmann, B. Grapevine water stress risk in perennial cover-cropping systems. Geol. Abh. Hess. 2004, 114, 93-104.

(C) 2017 by the authors; licensee MDPI, Basel, Switzerland. This article is an open access article distributed under the terms and conditions of the Creative Commons Attribution (CC BY) license (http:/ / creativecommons.org/licenses/by/4.0/). 